\title{
INTEGRATED MIDDLE AND LATE DEVONIAN MIOSPORE AND CHITINOZOAN ZONATION OF THE PARNAÍBA BASIN, BRAZIL: AN UPDATE
}

\author{
YNGVE GRAHN \\ Faculdade de Geologia, UERJ, Bloco A, Sala 4001, Rua São Francisco Xavier 524, Maracanã, 20550-013 \\ Rio de Janeiro, RJ, Brazil. yngvegrahn@hotmail.com \\ JOSÉ HENRIQUE G. DE MELO \\ Applied Biostratigraphy and Palaeoecology Management of Petrobras R \& D Center, Ilha do Fundão, 21941-598 \\ Rio de Janeiro, RJ, Brazil. jhmelo@petrobras.com.br \\ STANISLAS LOBOZIAK \\ Deceased
}

\begin{abstract}
New, hitherto unpublished miospore information from the Middle and Upper Devonian of the Parnaíba Basin, northeastern and north-central Brazil, has enabled refinement of the chitinozoan zonation recently proposed for that basin. To a large extent, Devonian miospore zones defined for the Amazonas Basin can be also recognized in the Parnaíba Basin and other Western Gondwanan basins. The miospore zones are discussed and compared to the coeval Southern Euramerican miospore zonation, the regional Petrobras palynozones, and to the chitinozoan zonation of the Parnaíba Basin, additional Western Gondwanan regions, and other parts of the world.
\end{abstract}

Key words: Chitinozoans, miospores, Middle/Late Devonian, Parnaíba Basin, Brazil.

RESUMO - Informações novas e até então inéditas acerca dos miósporos do Devoniano Médio e Superior da bacia do Parnaíba, no nordeste e centro-norte brasileiros, permitiram refinar o zoneamento de quitinozoários devonianos proposto recentemente para aquela bacia. Muitas das biozonas de miósporos erigidas no Devoniano da bacia do Amazonas podem ser também aplicadas à bacia do Parnaíba e outras bacias do Gondwana Ocidental. Essas biozonas são discutidas e comparadas com o zoneamento coetâneo de miósporos da Euramérica meridional, com as palinozonas regionais da Petrobras, e com os zoneamentos de quitinozoários da bacia do Parnaíba, de demais regiões do Gondwana Ocidental, e de outras partes do mundo.

Palavras-chave: Quitinozoários, miósporos, Devoniano Médio/Superior, bacia do Parnaíba, Brasil.

\section{INTRODUCTION}

Müller (1962) was the first to use palynomorphs in the Paleozoic biostratigraphy of the Parnaíba Basin, and his early regional scheme was later adopted and partly modified by others (Brito \& Santos, 1965; Brito, 1967, 1971; Quadros, 1982). Daemon $(1974,1976)$ and Andrade \& Daemon (1974) applied Daemon \& Contreiras' (1971) palynozonation (originally erected in the Amazonas Basin) to Devonian and Early Carboniferous strata of the Parnaíba Basin. Grahn et al. (2001) reviewed and updated previous palynostratigraphic schemes for the Parnaíba Basin, and Quadros (1982), Grahn et al. (2001) and Grahn \& Melo (2005) attempted to erect Middle and Late Devonian chitinozoan zonations for the same region. Grahn et al. (2005) described an integrated miospore-chitinozoan zonation for Silurian and Early Devonian sections of the basin.
Although information is still incomplete, chitinozoan occurrences in the Parnaíba Basin (and the adjacent Jatobá Basin) have been documented in many previous papers, e.g., Regali (1964), Sommer \& Boekel (1964), Lange (1967), Quadros (1982), Cardoso (1985), Cruz \& Quadros (1985), Grahn (1992), and Dino et al. (1996). In contrast, the Middle and Late Devonian miospores are relatively better known (Daemon, 1974; Streel, 1986; Loboziak et al., 1992, 1993, 2000; Rodrigues et al., 1995; Melo et al., 1999; Loboziak \& Melo, 2000, 2002; Streel et al., 2000a, 2001, and Melo \& Loboziak, 2001, 2003 plus unpublished data by the same authors), and a new miospore zonation of the Parnaíba Basin has been outlined by Melo \& Loboziak (2003:166, text-figure 16).

The present paper aims to correlate the Middle and Late Devonian miospore zonation erected by Melo \& Loboziak (2003) in the adjacent Amazonas Basin (but recognizable 
elsewhere in Brazil and South America) with coeval chitinozoan zonations of the Parnaíba Basin (Grahn \& Melo, 2005) and other Western Gondwanan regions (Grahn, 2005), and with the global Devonian chitinozoan zonation (Paris et al., 2000). In addition, the correlation of miospore and chitinozoan zones recognized in this paper with prior Petrobras zonal schemes of the Parnaíba Basin supplements the work of Grahn et al. (2001) and Melo \& Loboziak (2003). These earlier zonal units have not been used operationally in Brazilian basins since the late 1970's, because many are inadequately defined, partly misdated, and/or diachronous. Nevertheless, they are still alluded to in more recent reviews (e.g., Quadros, 1982; Molyneux et al., 1996; Streel et al., 2000a).

\section{GEOLOGICAL SETTING AND STRATIGRAPHY}

The present-day intracratonic Parnaíba Basin (formerly named Maranhão Basin in the geological literature) covers an area of ca. $600,000 \mathrm{~km}^{2}$ in northeast and north-central Brazil (Figure 1). The basin is delimited by the Tocantins and Ferrer/Urbano Santos Highs in the north, and by the São Francisco High in the south. Erosional remnants of Silurian and Devonian rocks from a former northnorthwestward extension of the Parnaíba Basin are present in at least the adjacent Marajó and Barreirinhas basins, which are downfaulted Mesozoic rift basins of the Brazilian equatorial continental margin. Outliers also occur to the east and southeast, the main ones being included within the Tucano and Jatobá rift basins. Middle and Late Devonian rock units of the Parnaíba Basin are, in ascending order, the Itaim, Pimenteira, Cabeças, and lowermost Longá formations (Grahn, 1992; Grahn \& Melo, 2005).

\section{MATERIALS AND METHODS}

In the period 1988-1989, 348 Devonian rock samples from 20 Petrobras deep-drillings and 20 outcrops in the Parnaíba Basin were examined for chitinozoans. Most of the samples investigated were cuttings, hence often contaminated by downhole caving materials. This hampered earlier efforts to achieve a definitive chitinozoan biostratigraphy encompassing the various formations in the basin. Subsequent miospore datings by Loboziak et al. (1992, 1993, 2000), Rodrigues et al. (1995), Melo et al. (1999), Loboziak \& Melo (2000, 2002), Grahn et al. (2001), and Streel et al. (2000a, 2001), augmented by a considerable amount of unpublished data, managed to establish reliable correlation of regional Devonian miospore successions with the standard Southern Euramerican miospore zonation. Moreover, those miospore studies facilitated the separation of reworked from in situ chitinozoan species, since the actual chitinozoan ranges could be dated independently with the aid of a different microfossil group, whose stratigraphic successions are well established on both global and regional bases (Streel et al., 2000b; Melo \& Loboziak, 2003). Outcrop and well localities considered in this paper are shown in Figures 1 and 2.

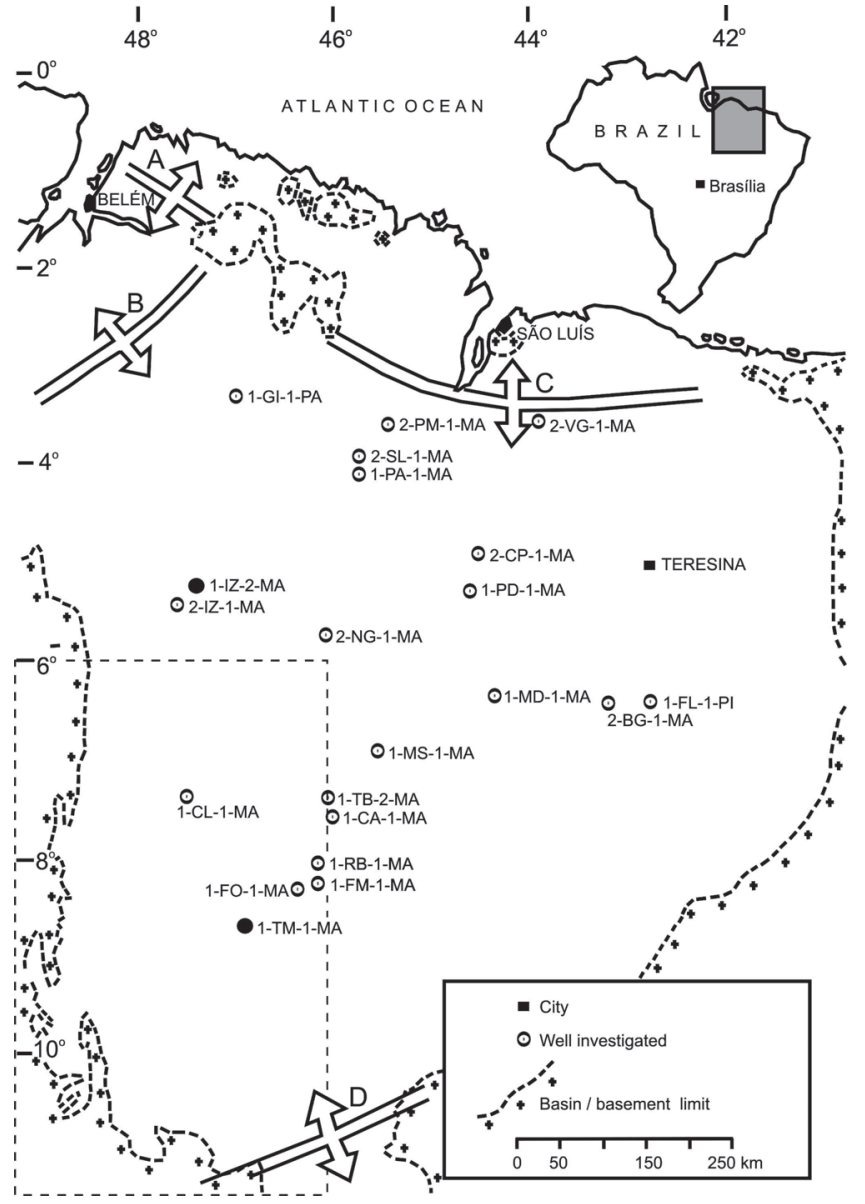

Figure 1. Location map of Parnaíba Basin wells investigated in this study (modified from Grahn \& Melo, 2005). Structural Highs: A, Guamá; B, Tocantins; C, Ferrer/Urbano Santos; D, São Francisco. Dashed rectangle on lower left-hand corner corresponds approximately to the area detailed in Figure 2.

\section{MIDDLE AND LATE DEVONIAN MIOSPORE AND CHITINOZOAN ZONES OF THE PARNAÍBA BASIN}

To a large extent, the Devonian miospore zones erected in the Amazonas Basin by Melo \& Loboziak (2003) also apply to the adjacent Parnaíba Basin (Grahn et al., 2005; Melo \& Loboziak, 2003). Two distinct intervals with missing or condensed sedimentary sections occur in the Middle to Late Devonian interval of the Parnaíba Basin. The oldest of these spans from the late Givetian to the earliest Frasnian (upper part of the Trg miospore zone of Melo \& Loboziak, 2003), and the youngest corresponds to the late Famennian ( $\operatorname{Rad}$ and possibly Hys miospore zones). However, there is indirect paleontological evidence of the presence of late Famennian (pre-“Strunian", Hys Zone-age) rocks in at least the northcentral part of the Parnaíba Basin. Here, Carozzi et al. (1975) and Niklas et al. (1976) record the problematic fossil plant Protosalvinia in undesignated core samples from well 2-SL1-MA. In the Amazonas Basin, occurrences of Protosalvinia spp. are restricted to sections of the lower Curiri Formation 


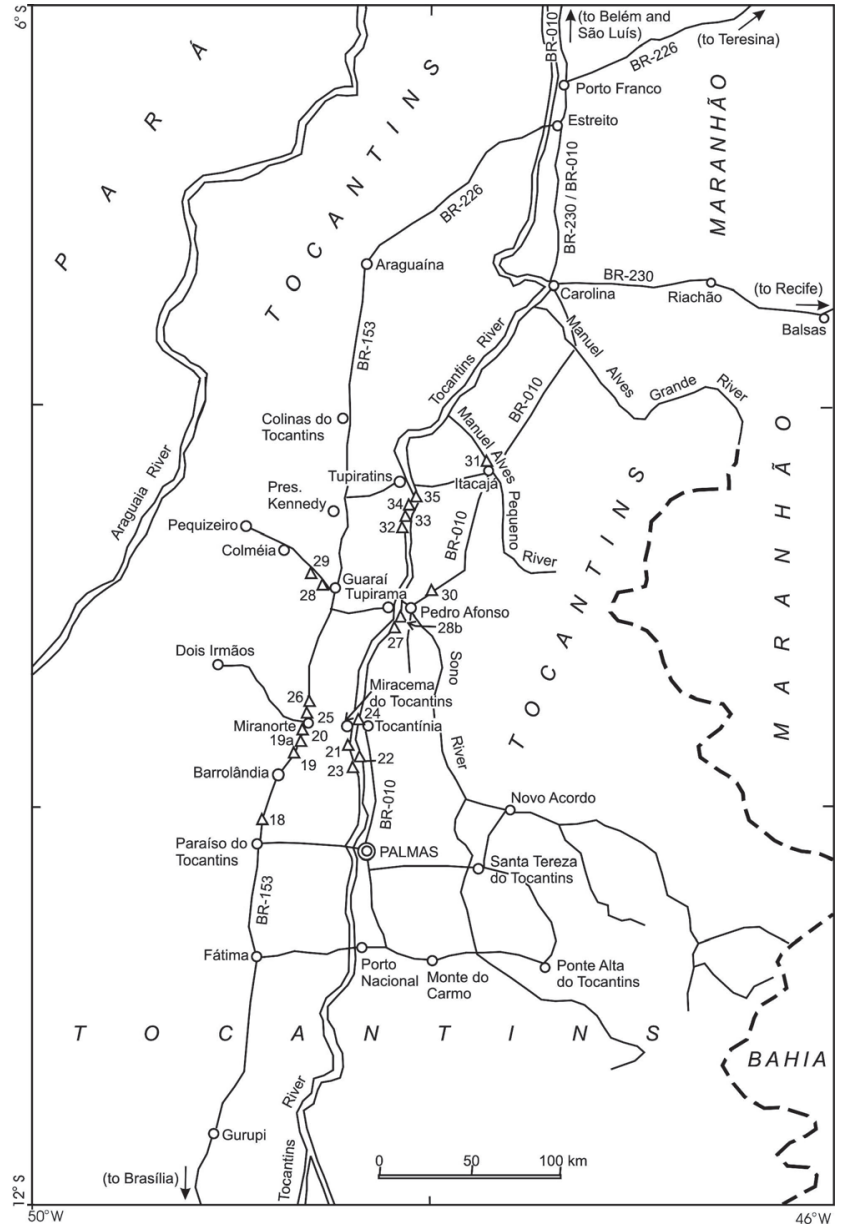

Figure 2. Location map of outcrops sampled (numbered triangles) on the western flank of the Parnaíba Basin (modified from Loboziak et al., 2000; Grahn \& Melo, 2005).

(Loboziak et al., 1997a, 1997b) which are nowadays assigned to the Hys Zone (Melo \& Loboziak, 2003).

It should be noted that miospore assemblages diagnostic of the latest Famennian, early "Strunian" LL (Retispora lepidophyta - Knoxisporites literatus) Interval Zone of the Ardenne-Rhenish zonation (Streel et al., 1987; Maziane et al., 1999) are also unknown in the Parnaíba and Amazonas basins (Melo \& Loboziak, 2003). In addition, latest Frasnian - middle Famennian rocks (equivalent to the TP miospore zone of Melo \& Loboziak, 2003), although probably present, are still inadequately characterized by miospores in the Parnaíba Basin, because almost no zonal or characteristic species have been thus far identified within that particular interval.

Stratigraphic ranges of selected Middle-Late Devonian miospores of the Parnaíba Basin are given in Figure 3, and they are listed in Appendix 1. The coeval miospore zones defined by Melo \& Loboziak (2003) in the Amazonas Basin and recognized in the Parnaíba Basin are briefly discussed below. A more detailed study of Devonian-Tournaisian palynofloras and biozones in the latter basin will be the subject of a separate paper by the present authors. See also Melo \& Loboziak (2000) for an account of the regional Visean miospore stratigraphy.
A regional chitinozoan zonation for the Middle and Upper Devonian of the Parnaíba Basin was described by Grahn \& Melo (2005), and compared to other coeval chitinozoan zones of Western Gondwana by Grahn (2005). In this paper, these zonations are also compared to the global chitinozoan zonation (Paris et al., 2000), and to the miospore zones of the Amazonas Basin and Western Gondwana (Melo \& Loboziak, 2003), Ardenne-Rhenish regions (Streel et al., 1987; Maziane et al., 1999), and the Old Red Sandstone Continent and adjoining areas (Richardson \& McGregor, 1986; Richardson \& Ahmed, 1988; Figures 3 and 5). The stratigraphic ranges of selected Middle-Late Devonian chitinozoan species of the Parnaíba Basin are shown in Figure 4 and listed in Appendix 2. The correlation between the regional chitinozoan and miospore zonations is given in Figure 5 and discussed below. Figure 5 also compares the aforementioned biozonations to coeval zonal schemes applied by Petrobras to the Parnaíba Basin.

\section{Grandispora/Samarisporites spp. Interval Zone (GS)}

The base of this zone is defined by the stratigraphic inception of large spinose pseudosaccates / zonates belonging to the Grandispora / Samarisporites spp. (GS) complex. In the Ardenne-Rhenish miospore zonation (Streel et al., 1987), these forms are known to first occur and proliferate around the transition between the Emphanisporites foveolatusVerruciretusispora dubia (FD) and Acinosporites apiculatusGrandispora protea (AP) Oppel Zones. In Western Europe, this interval corresponds to the serotinus through costatuspatulus conodont zones of latest Emsian age. Acinosporites lindlarensis, Emphanisporites annulatus and Grandispora douglastownense are among the characteristic miospore species of the GS miospore zone in the Parnaíba Basin, although some have earlier stratigraphic inceptions elsewhere (Melo \& Loboziak, 2003). Early Devonian holdovers, such as Archaeozonotriletes chulus, Dictyotriletes emsiensis, Synorisporites spp., and several small non-spinose zonates, have not been found above the GS miospore zone. In the Parnaíba Basin, this biozone corresponds to the main (poorly palyniferous) part of the sandy Itaim Formation (Figure 3), of latest Emsian-early Eifelian age. Thus far, no chitinozoans have been reported from this stratigraphic interval, probably due to unsuitable littoral to transitional and nonmarine lithofacies that prevail in the Itaim Formation.

In terms of the former Petrobras regional palynozonations, the same interval correlates chiefly with palynozone $S$ (Müller,

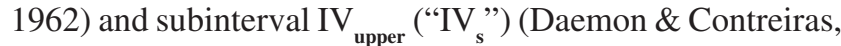
1971; Andrade \& Daemon, 1974), according to the most recent reviews (Grahn et al., 2001; Melo \& Loboziak, 2003).

\section{Grandispora permulta Interval Zone (Per)}

The base of this zone is defined by the first occurrence of Grandispora permulta. Other characteristic species that first occur within this zone in the Parnaíba Basin (Figure 3) include Camarozonotriletes? concavus, Craspedispora ghadamisensis, Grandispora libyensis, several other Grandispora spp., Verrucosisporites premnus and V. scurrus (Melo \& Loboziak, 2003). This stratigraphic interval corresponds to the 
uppermost Itaim and basal Pimenteira formations of the Parnaíba Basin (Loboziak et al., 1992, 1993; Loboziak \& Melo, 2000, 2002), and its age span is late early Eifelian to earliest Givetian. According to Melo \& Loboziak (2003), the Per Zone is the Western Gondwanan equivalent of the pre-Lem part of the Acinosporites acanthomammillatus-Densosporites devonicus (AD) Oppel Zone of the Ardenne-Rhenish Devonian miospore zonation (Streel et al., 1987).

The Per miospore zone corresponds to two successive chitinozoan zones in the Parnaíba Basin (Grahn \& Melo, 2005). The first occurrence of Ancyrochitina latipes defines the base of the homonymous Interval Range Zone, and the introduction of A. langei, together with A. latipes, marks the base of the succeeding Ancyrochitina latipes-Ancyrochitina langei Concurrent Range Zone. Ancyrochitina latipes was originally described from the Solon Member of the Little Cedar Formation in Illinois (Collinson \& Scott, 1958), which corresponds to the middle and upper parts of the varcus conodont zone (late early to earliest late Givetian; Wright, 1980; Witzke et al., 1988). The total range of $A$. latipes in the Parnaíba Basin is mainly restricted to the Eifelian, whereas A. cornigera first occurs in the latest Eifelian in that same region. However, it should be noted that Collinson \& Scott (1958) did not report any chitinozoans from rocks older than the Solon Member. Near the base of the A. latipes Interval Range Zone, within the uppermost Itaim Formation, the first Middle Devonian chitinozoans of the Parnaíba Basin appear (e.g., Ancyrochitina arirambaense, A. latipes, and Fungochitina pilosa). A slightly younger (late Eifelian) inception of $F$. pilosa is generally recorded elsewhere in Western Gondwana. Upsection, within the basal Pimenteira Formation, the late Eifelian part of the biozone has the regional first occurrences of Alpenachitina eisenacki, Ancyrochitina cornigera (latest Eifelian), A. langei, and Spinachitina aff. S. biconstricta. In its type area (Midcontinent U.S.A.), A. eisenacki ranges from the early Eifelian partitus conodont zone into the late early Givetian varcus Zone (Wright, 1980). The species also appears in late early Eifelian strata of the Amazonas Basin (Grahn \& Melo, 2004) and Southern Subandean Bolivia (Huamampampa Formation; Grahn, 2002). Unsuitable lithologies prevalent in the Itaim Formation probably account for the absence of $A$. eisenacki in the lower Eifelian of the Parnaíba Basin, although it is well represented in early Givetian sections of this and other intracratonic basins of Brazil (Grahn et al. 2002; Gaugris \& Grahn, 2006). Urban \& Newport (1973) reported A. cornigera from the earliest Givetian Davenport Member of the Wapsipinicon Formation, but found no chitinozoans in the late Eifelian part of the same formation. Angochitina daemoni and Ramochitina ramosi are late Emsian holdovers that range throughout the Eifelian and early Givetian (Grahn, 2005). Taken together, the A. latipes and A. latipes-A. langei Range Zones of the Parnaíba Basin roughly equate to the Alpenachitina eisenacki Interval Range Zone of the Western Gondwanan biozonation (Grahn, 2005). Globally, the A. eisenacki Interval Range Zone is more restricted (late early Eifelian), and is followed by the Eisenackitina aranea Interval Range Zone which extends into the "middle" (i.e., late early) Givetian. The range of E. aranea in Western Gondwana is apparently somewhat shorter than elsewhere, because the species is as yet unreported from Western Gondwanan strata younger than early Givetian. In the case of the Parnaíba Basin, this is probably a consequence of younger Givetian strata being not widely developed regionally, whereas they seem to be more complete at least in the Paraná Basin (Loboziak et al., 1988; Grahn et al., 2002; Gaugris and Grahn, 2006). The first occurrence of $E$. aranea in the Parnaíba Basin is probably coeval with the costatus conodont zone, which is in agreement with the species' first occurrence in the Midcontinent U.S.A. (Wright, 1980).

According to Grahn et al. (2001) and Melo \& Loboziak (2003), the Middle Devonian interval under consideration is largely equivalent to palynozone R (Müller, 1962) and subinterval $V_{\text {lower }}$ ("V,") (Daemon \& Contreiras, 1971; Andrade \& Daemon, 1974), in terms of Petrobras' pioneer regional palynozonations of the Parnaíba Basin.

\section{Geminospora lemurata-Chelinospora ex gr. ligurata Interval Zone (LLi)}

The base of this zone is defined by the lowest occurrence of Geminospora lemurata and/or coarsely baculate-reticulate patinates of the Chelinospora ex gr. ligurata complex (comprising $C$. ligurata s.s. and closely allied forms). Furthermore, Archaeozonotriletes variabilis also has its regional first occurrence within the biozone (Figure 3). The LLi Zone is the Western Gondwanan equivalent of the Lem Interval Zone (within the AD Oppel Zone) of the ArdenneRhenish Devonian miospore zonation (Streel et al., 1987). This interval is widespread in the Parnaíba Basin, encompassing much of the lower Pimenteira Formation, and is dated early Givetian (Loboziak et al., 1992, 1993, 2000; Loboziak \& Melo, 2000, 2002). It is likely that a similar age is assignable to the oldest sections of the sandier Cabeças Formation on the eastern rim of the Parnaíba Basin, where the unit is best developed, and laterally replaces the upper Pimenteira pelites (Loboziak et al., 2000). Although consistent with marine megafossil evidence (Melo, 1988), this hypothesis is not yet demonstrable on palynological grounds.

The LLi Zone is approximately equivalent to the Ramochitina stiphrospinata Total Range Zone, in terms of the chitinozoan zonations of both the Parnaíba Basin (Grahn $\&$ Melo, 2005) and Western Gondwana (Grahn, 2005). With reference to the global zonation (Paris et al., 2000), the LLi Zone corresponds to a part of the upper Eisenackitina aranea Interval Range Zone (Figure 5). The base of the $R$. stiphrospinata Total Range Zone shows an increase in abundance and diversity of chitinozoans, with the appearance of many new species. The eponymous species, as well as Ancyrochitina postdesmea, A. simplex and Linochitina jardinei are all restricted to the zone, whereas species such as Ancyrochitina morzadeci and A. taouratinensis range into the late early Givetian. In the Paraná Basin, A. taouratinensis occurs also in late Givetian strata (Gaugris \& Grahn, 2006). Linochitina jardinei is the index species of a global late Givetian chitinozoan zone. However, L. jardinei has not been reported from late Givetian beds in Western Gondwana, where 
these are only known for certain in relatively few regions, e.g., the Paraná Basin (Grahn et al., 2002; Gaugris \& Grahn, 2006), Argentina (Ottone, 1996; Grahn, 2005), and Bolivia (Racheboeuf et al., 1993; Melo, 2000; Grahn, 2002, 2005).

According to Grahn et al. (2001) and Melo \& Loboziak (2003), early to late early Givetian strata of the Parnaíba Basin (i.e., encompassing the combined LLi-Trg miospore zones and the coeval chitinozoan zones-see comments below) correlate primarily with Müller's (1962) palynozone $\mathrm{Q}_{\text {lower }}$ (“Q $\mathrm{Q}_{\mathrm{i}}$ ”) as well as subinterval $\mathrm{V}_{\text {upper }}$ ("V $\mathrm{V}_{\mathrm{s}}$ ") of Daemon \& Contreiras (1971) and Andrade \& Daemon (1974), in terms of the older Petrobras regional biozonations. According to Grahn et al. (2001, textfigure 2 A), Müller's succeeding palynozone, $Q_{\text {upper }}$ (“ $Q_{\text {s }}$ ), which is usually restricted to the Frasnian, also contains a characteristic Givetian chitinozoan fauna in at least one central Parnaíba Basin well (1-MD-1-MA, core no. 28).

\section{Samarisporites triangulatus Interval Zone (Trg)}

The base of this zone is defined by the first occurrence of Samarisporites triangulatus. The proliferation of Cymbosporites catillus and C. cyathus, and a more consistent presence of Chelinospora paravermiculata, are other characteristic features of the Trg miospore palynofloras (Rodrigues et al., 1995; Melo \& Loboziak, 2003). All of these species co-occur in the Pimenteira Formation (Rodrigues et al., 1995; Loboziak et al., 2000), where only the lower part of the biozone is represented. Its upper part, of late Givetianearliest Frasnian age, is seemingly missing in the Parnaíba Basin (Figure 3). Indeed, the Trg Zone is highly condensed (Rodrigues et al., 1995) and poorly documented in central and western parts of the basin. It seems to be represented in only a narrow band in the upper part of the lower Pimenteira Formation, with a restricted late early Givetian age, equivalent to the Samarisporites triangulatus-Ancyrospora ancyrea var. ancyrea (TA) Oppel Zone of the Ardenne-Rhenish miospore zonation (Streel et al., 1987). Elsewhere in South America, e.g., in the Paraná Basin and Bolivia (Loboziak et al., 1988; Melo, 2000), the total age span of the Trg Zone is late early Givetian through earliest Frasnian (Melo \& Loboziak, 2001, 2003), which is equivalent to the combined TA and TCo ( $S$. triangulatus-Chelinospora concinna) Oppel Zones of Western Europe (Streel et al., 1987).

The late early Givetian interval of the Trg Zone corresponds to the Fungochitina microspinosa Interval Range Zone in the Parnaíba Basin (Grahn \& Melo, 2005). Fungochitina microspinosa is a long-ranging Devonian species (late early Givetian-middle Famennian) which first occurs at the base of this chitinozoan zone. Species restricted to the lower part of the zone include Lagenochitina sp. B (sensu Grahn \& Melo, 2005) and Ramochitina pimenteiraense. The top of this interval is characterized by the regional disappearance of such typical Middle Devonian species as Ancyrochitina morzadeci and Spinachitina aff. S. biconstricta. The F. microspinosa Interval Range Zone is coeval with the lower part of the Fungochitina microspinosaAncyrochitina taouratinensis Interval Range Zone of the Western Gondwanan biozonation (Grahn, 2005).
Ancyrochitina taouratinensis has an early-late Givetian range in the Paraná Basin, where the Western Gondwanan zone is defined (Grahn, 2005; Gaugris \& Grahn, 2006). In global terms, the F. microspinosa Interval Range Zone corresponds to the upper part of the Eisenackitina aranea Interval Range Zone and to the lower part of the succeeding Ancyrochitina cornigera Interval Range Zone (Paris et al., 2000).

\section{Verrucosisporites bulliferus-Geminospora piliformis Interval Zone (BPi)}

The base of this zone is defined by the introduction of Verrucosisporites bulliferus. Other characteristic features include the incomings of Geminospora piliformis and the appearence of Samarisporites sp. E sensu Streel \& Loboziak (1987). The lower part of the zone is coeval with the $V$. bulliferus-Cirratriradites jekhowski (BJ) Oppel Zone of the Ardenne-Rhenish Devonian miospore zonation (Streel et al., 1987). In addition, the upper part of the BPi Zone, equivalent to the V. bulliferus-Lophozonotriletes media (BM) Oppel Zone of Western Europe (characterized by the stratigraphic inception of Lophozonotriletes spp.), has been recognized in outcrops on the western margin of the Parnaíba Basin (Loboziak et al., 2000). In central and western parts of the basin, the BPi Zone corresponds to the lower part of the upper Pimenteira Formation, and is dated as early Frasnian (Rodrigues et al., 1995; Loboziak et al., 2000).

In the Parnaíba Basin, these beds correspond to the lower part of the Lagenochitina avelinoi Interval Range Zone (Grahn $\&$ Melo, 2005). Angochitina katzeri is restricted to this interval, and important Late Devonian species such as Angochitina mourai, Lagenochitina avelinoi and Ramochitina kegeli have their regional first occurrences at the base of the zone. The lower part of the L. avelinoi Interval Range Zone (Grahn \& Melo, 2005) correlates with the lower part of the Hoegisphaera glabra Interval Range Zone of the Western Gondwanan (Grahn, 2005) and global (Paris et al., 2000) biozonations. The lowest Frasnian (uppermost Trg miospore zone) is not recognized in the Parnaíba Basin (Rodrigues et al., 1995; Loboziak et al., 2000), and probably corresponds to the Ramochitina viridarium Interval Range Zone of the global Devonian chitinozoan zonation (Paris et al., 2000).

The inadequate definition and miscorrelation of Late Devonian units of Petrobras pioneer palynozones in northern Brazilian basins pose serious problems to their accurate dating and comparison to palynozones now in use for the same regions (Melo et al., 1999; Grahn et al., 2001; Melo \& Loboziak, 2003). Nonetheless, early to early late Frasnian strata of the Parnaíba Basin correspond generally to at least palynozone $\mathrm{Q}$ upper (“Q $\mathrm{Q}_{\mathrm{s}}$ ”, locally also parts of $\mathrm{Q}_{\text {lower }}$, i.e., “Q $\mathrm{Q}_{\mathrm{i}}$ ”) of Müller (1962), and interval VI sensu Daemon \& Contreiras (1971), Andrade \& Damon (1974), and Daemon (1974, 1976). These rocks encompass the combined BPi and BMu miospore zones (see below), and the entire L. avelinoi chitinozoan zone.

Rugospora bricei-Diducites mucronatus Interval Zone (BMu)

The base of this zone is defined by the first occurrence of Rugospora bricei and/or Diducites mucronatus. Another 
species that appears initially within this interval in the Parnaíba Basin is Auroraspora macra. The scarcity of Verrucosisporites bulliferus and a marked decline in the abundance and diversity of the GS-complex characterize the biozone. Altogether, these features suggest correlation of the BMu Zone with at least the lower part of phase zone "IV" ("IV" ") of the Ardenne-Rhenish Devonian miospore zonation (Streel et al., 1987). In central and western parts of the Parnaíba Basin, the BMu Zone corresponds to the main part of the upper Pimenteira Formation of late Frasnian age (Melo \& Loboziak, 2003).

This stratigraphic interval is poorly characterized by chitinozoans in the Parnaíba Basin, where it corresponds to the upper part of the L. avelinoi Interval Range Zone (Grahn
\& Melo, 2005). Angochitina rathbuni, Hoegisphaera glabra s.s. and Lagenochitina sommeri have their regional first occurrences at the base of the upper $L$. avelinoi Interval Range Zone, which is coeval with the upper $\mathrm{H}$. glabra Interval Range Zone of both the Western Gondwanan (Grahn, 2005) and global (Paris et al., 2000) Devonian chitinozoan zonations.

\section{Teichertospora torquata-Auroraspora pseudocrista Interval Zone (TP)}

This zone, of latest Frasnian to possibly middle Famennian age (Melo \& Loboziak, 2003), is envisaged as the Western Gondwanan equivalent of the Auroraspora torquataGrandispora gracilis Assemblage Zone, in terms of the Old

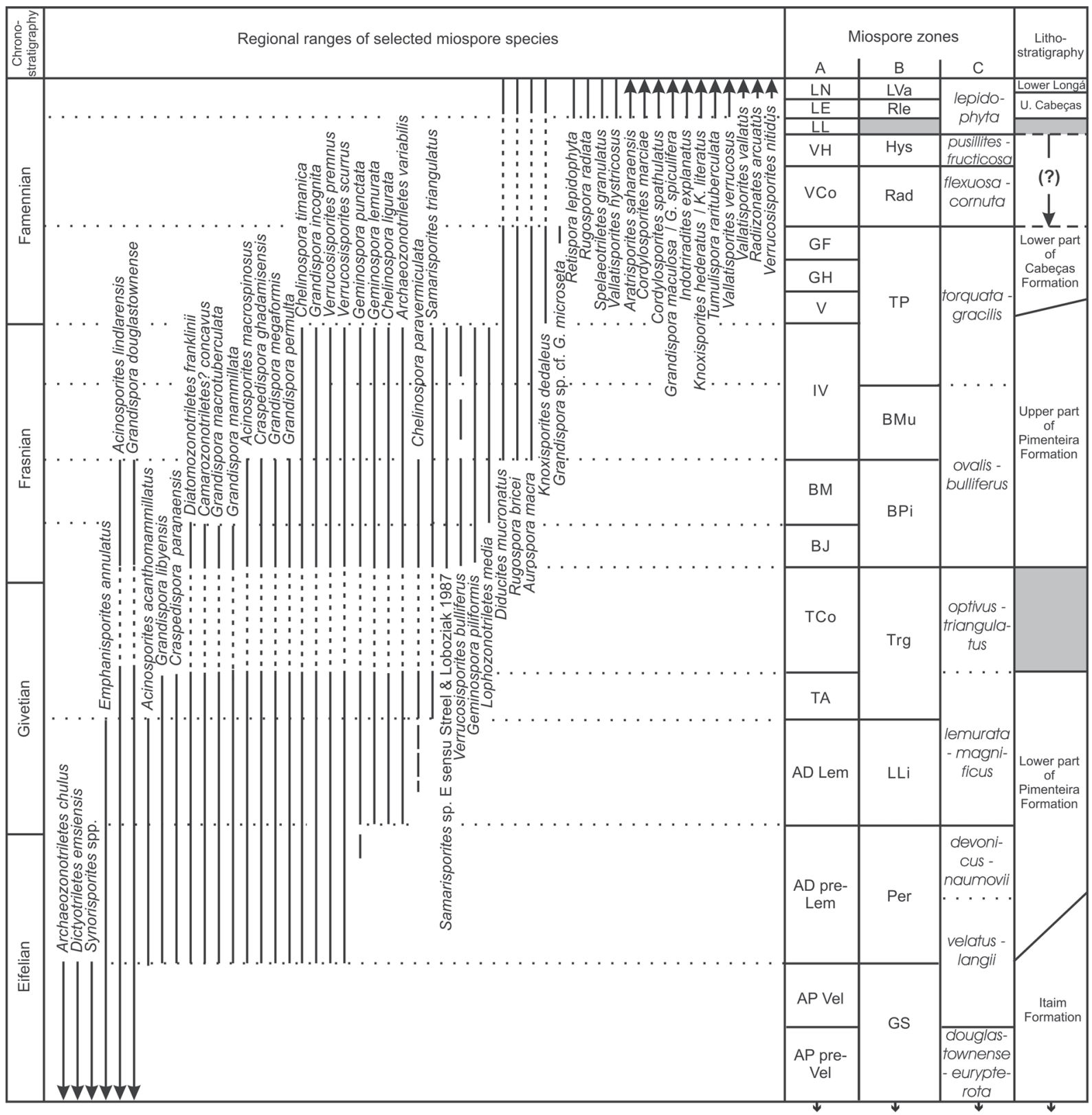

Figure 3. Range chart of selected Middle and Late Devonian miospore species in central and western parts of the Parnaiba Basin. The downward-pointing arrow within the Famennian interval of the lithostratigraphy column indicates a possible late Famennian extension of the minimum pre-"Strunian" gap in the basin, based on palynological data presented herein (see text). Miospore zonations: A, ArdenneRhenish (Streel et al., 1987; Maziane et al., 1999); B, Western Gondwanan (Melo \& Loboziak, 2003); C, Old Red Sandstone Continent (Richardson \& McGregor, 1986; Richardson \& Ahmed, 1988). 
Red Sandstone Continent Devonian miospore zonation (Richardson \& McGregor, 1986; Richardson \& Ahmed, 1988). In the Amazonas Basin, the base of the TP Zone is defined by the first occurrence of Teichertospora torquata and/or Auroraspora pseudocrista. Neither of these species has been identified thus far in the Parnaíba Basin. Nevertheless, coeval palynofloras probably occur within the uppermost Pimenteira and lower Cabeças formations in central and western parts of the basin (Loboziak \& Melo, 2000, 2002). Indeed, these two rock units (in well 1-TM-1-MA, southwestern Parnaíba Basin; Figure 1) include the regional first occurrences of Knoxisporites dedaleus and Grandispora sp. cf. G. microseta, respectively. The former species characterizes the base of phase zone "V" in Western Europe (Streel et al., 1987), which coincides approximately to the Frasnian-Famennian boundary (Figure 3). In turn, G. microseta is a characteristic species of the late Famennian GF Zone of the ArdenneRhenish miospore zonation (Streel et al., 1987), which is only doubtfully identified in the Famennian of the Parnaíba Basin.

Stratigraphically higher, the late Famennian Rugospora radiata (Rad) and Vallatisporites hystricosus (Hys) Interval Zones (which succeed the TP Zone in the Amazonas Basin) have not yet been recognized in the Parnaíba Basin (Melo \& Loboziak, 2003). Here, their eponymous species are thus far only recorded in latest Famennian ("Strunian") strata of the uppermost Cabeças Formation and lowermost Longá

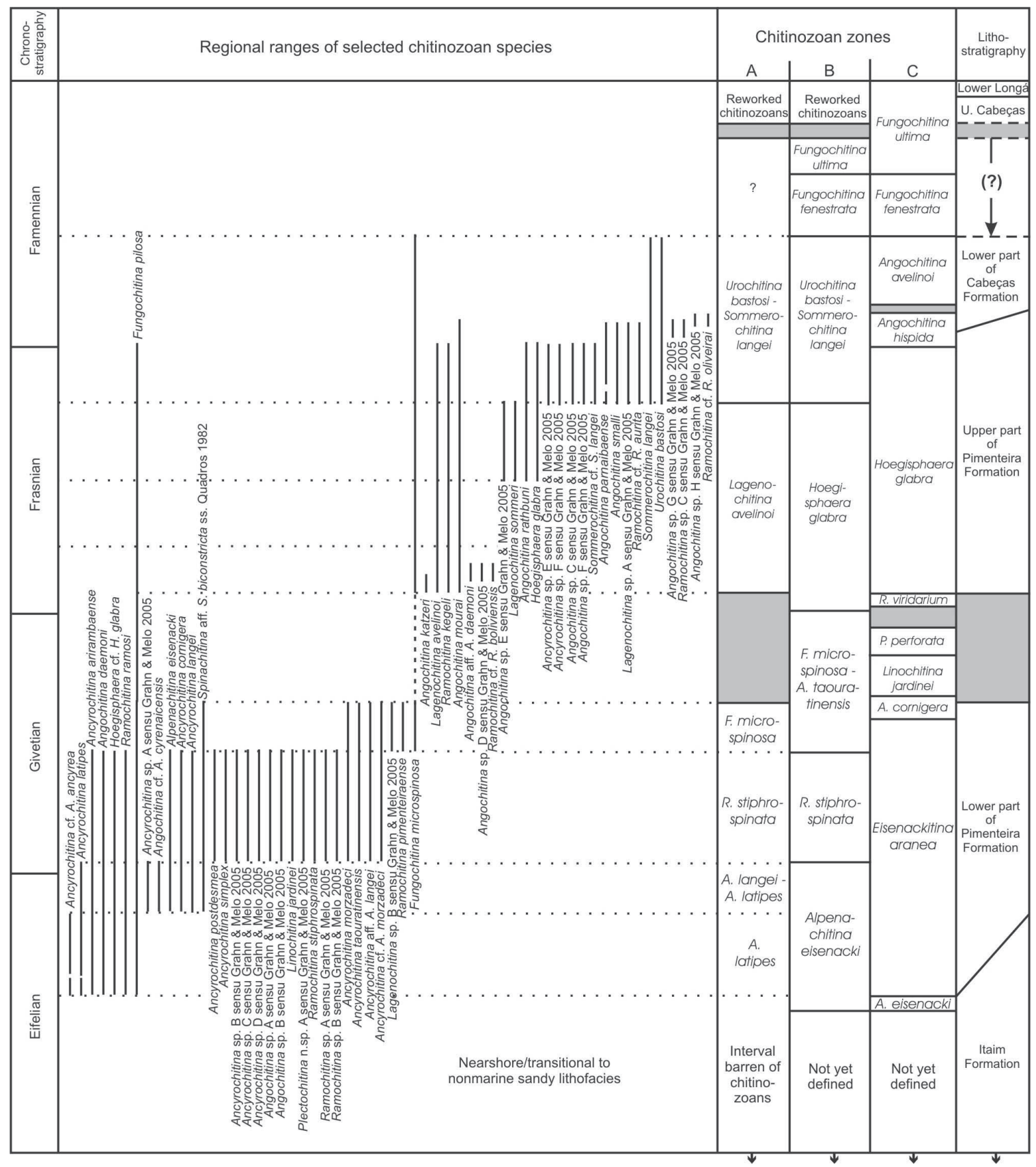

Figure 4. Range chart of selected Middle and Late Devonian chitinozoan species in central and western parts of the Parnaíba Basin. Late Famennian downward-pointing arrow as explained in the caption of Figure 3. Chitinozoan zonations: A, Parnaíba Basin (Grahn \& Melo, 2005); B, Western Gondwanan (Grahn, 2005); C, Global Devonian (Paris et al., 2000). 
Formation, together with Retispora lepidophyta and its usual associates (Figure 3).

Contrary to the other stratigraphic intervals considered in this paper, the latest Frasnian-middle(?) Famennian one is thus far only known from the subsurface of the basin. It contains a distinct chitinozoan fauna, diagnostic of the Urochitina bastosi-Sommerochitina langei Concurrent Range Zone in terms of both the Parnaíba Basin (Grahn \& Melo, 2005) and Western Gondwanan (Grahn, 2005) biozonations. At least five species make their first appearance at the base of this zone: viz., Angochitina parnaibaense, A. smalli, Lagenochitina sp. A sensu Grahn \& Melo, 2005, Sommerochitina langei, and Urochitina bastosi. In addition, a complex of Ancyrochitina and Angochitina species (provisionally left in open

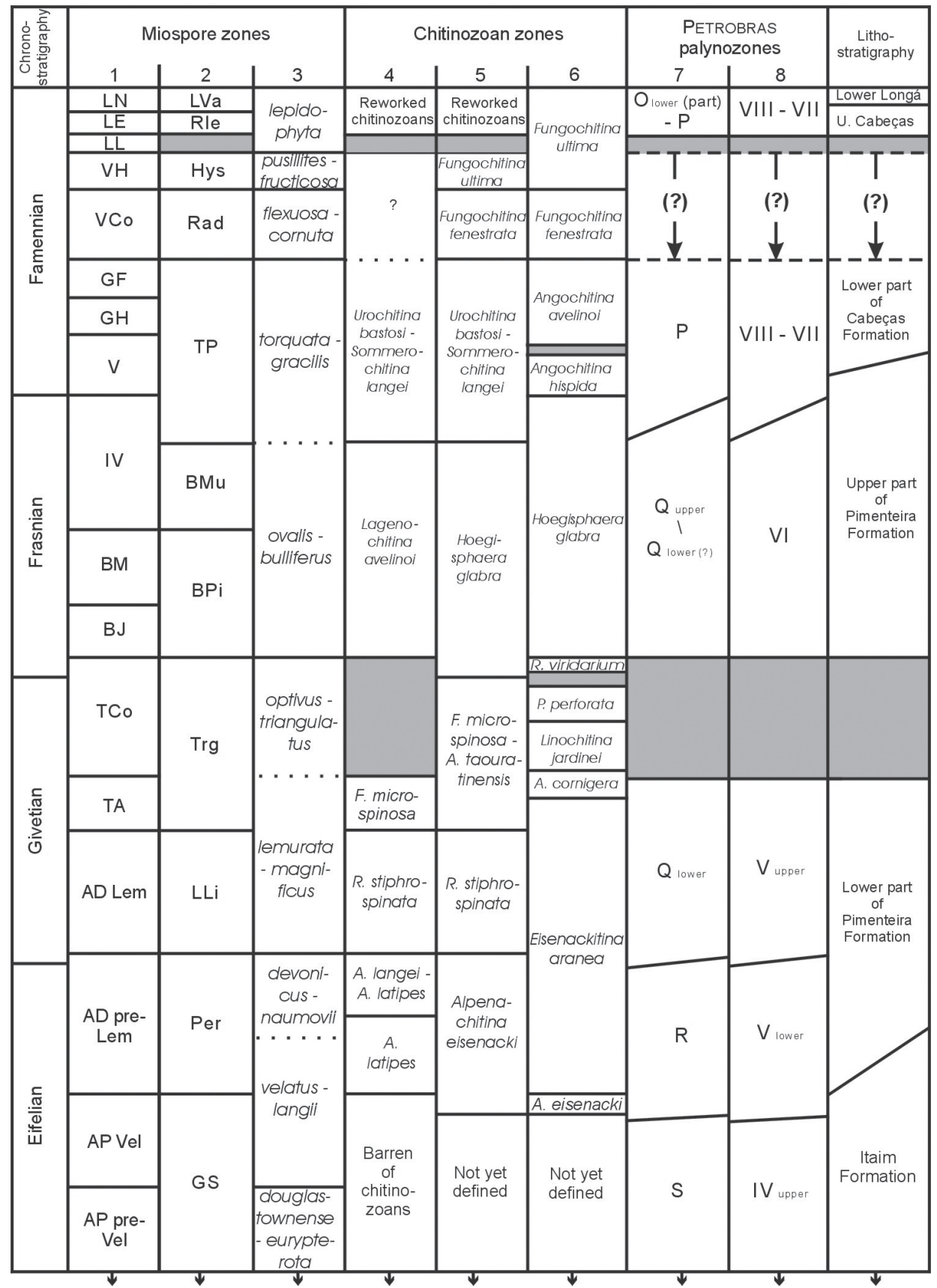

Figure 5. Comparison of current Middle- Late Devonian miospore and chitinozoan zonations with traditional Petrobras regional palynozones in the Parnaíba Basin. Age and relationships of rock units shown in the lithostratigraphy column apply only to central and western parts of the basin. Late Famennian downward-pointing arrows as explained in the caption of Figure 3. Miospore zonations: 1, Ardenne-Rhenish (Streel et al., 1987; Maziane et al., 1999); 2, Western Gondwanan (Melo \& Loboziak, 2003); 3, Old Red Sandstone Continent and adjacent regions (Richardson \& McGregor, 1986; Richardson \& Ahmed, 1988). Chitinozoan zonations: 4, Parnaíba Basin (Grahn \& Melo, 2005); 5, Western Gondwanan (Grahn, 2005); 6. Global (Paris et al., 2000). Petrobras regional palynozonations: 7, after Müller (1962); 8, after Daemon (1974, 1976) and Andrade \& Daemon (1974). Age and correlation of Petrobras palynozones in the Parnaíba Basin updated and calibrated according to Grahn et al. (2001) and Melo \& Loboziak (2003), modified by new data presented herein. 
nomenclature) also first appears regionally at the base of the zone (Figure 4). Stratigraphically higher, in the middle part of the zone, an interval of reduced thickness at the base of Famennian contains four, probably new species of the genera Angochitina and Ramochitina. Grahn et al. (2001) had proposed a late Frasnian first occurrence and total stratigraphic range for $U$. bastosi, and a somewhat younger (latest Frasnian) initiation for S. langei in the Parnaíba Basin. However, new miospore evidence in this study indicates a nearcontemporaneous first appearance for both chitinozoan species in the latest Frasnian, within an interval equivalent to the lower part of the TP miospore zone (Figures 4 and 5 herein; Grahn, 2005). Moreover, both $U$. bastosi and S. langei seem to persist well into at least the early or middle Famennian. The Urochitina bastosi-Sommerochitina langei Concurrent Range Zone corresponds globally to the uppermost Hoegisphaera glabra, the Angochitina hispida and A. avelinoi Interval Range Zones (Paris et al., 2000). Note that, according to Grahn \& Melo (2005), Angochitina avelinoi sensu Paris et al. (2000) (non Lange, 1952) is synonymous with A. smalli.

The latest Frasnian-middle(?) Famennian stratigraphic interval of the Parnaíba Basin corresponds mainly to

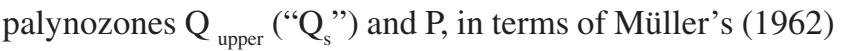
regional biozonation (Grahn et al., 2001). In turn, because of imprecisions involving the recognition and tracing of Daemon \& Contreiras' (1971) Late Devonian palynozones, local attributions for that same interval across the basin may vary from units VI through VIII (Andrade \& Daemon, 1974; Daemon, 1974, 1976), depending on the well studied.

\section{Retispora lepidophyta (Rle) and Retispora lepidophyta- Vallatisporites vallatus (LVa) Interval zones}

The base of the Rle Zone is defined by the regional introduction of Retispora lepidophyta (often associated with Indotriradites explanatus), and the base of the LVa zone by the regional first appearance of Vallatisporites vallatus and continued occurrence of Retispora lepidophyta. Other first occurrences of distinctive miospore species characterize the two biozones, e.g.: Cordylosporites marciae, C. spathulatus, Knoxisporites hederatus, K. literatus and Tumulispora rarituberculata in the Rle Zone, joined by Radiizonates arcuatus and Verrucosisporites nitidus in the LVa Zone. These two units are scarcely separable in the Parnaíba Basin, partly because coeval sections have not been studied in sufficient detail, and partly because their palynofloras were recycled and mixed as a consequence of the end-Devonian glaciation. In the Parnaíba Basin, this interval corresponds to the uppermost Cabeças Formation (Rle and LVa zones) and lowermost Longá Formation (LVa Zone). The age of both biozones is latest Famennian, or "Strunian" (Loboziak et al., 2000; Melo \& Loboziak, 2003). In terms of the Western European Devonian miospore zonation (Streel et al., 1987; Maziane et al., 1999), they are equivalent to the combined Retispora lepidophytaHymenozonotriletes explanatus (LE) and R. lepidophytaVerrucosisporites nitidus (LN) Interval Zones.

Coeval chitinozoan zones are not recognized in the Parnaíba Basin. The Western Gondwanan chitinozoan zonation (Grahn, 2005) includes two late Famennian zones, which are unknown in the study area (Figures 4 and 5). The Fungochitina fenestrata Total Range Zone (Grahn, 2005) equates to the homonymous zone of the global biozonation (Paris et al., 2000), and corresponds roughly to the Rugospora radiata (Rad) miospore zone. The Fungochitina ultima Zone (Grahn, 2005) corresponds to only the lowest part of the homonymous zone of the global biozonation (Paris et al., 2000), and to the entire Vallatisporites hystricosus (Hys) miospore zone. In the Parnaíba Basin, reworked Middle and Late Devonian chitinozoans and other palynomorphs, derived mainly from the Pimenteira and lower Cabeças formations, occur commonly in tillites and glaciomarine strata of latest Famennian age, within the uppermost Cabeças Formation and lowermost Longá Formation.

The difficulties inherent in the identification of Late Devonian units of Petrobras former biozonations are heightened in the "Strunian" section of northern Brazilian basins by very conspicuous palynomorph reworking. In the Parnaíba Basin, Müller's (1962) zonal assignments for this interval generally involve parts of $\mathrm{P}$ to $\mathrm{O}_{\text {lower }}$ (“O,") (Figure 5 ), depending on the particular well, but less frequently may include "lower" or "higher" units such as $\mathrm{Q}_{\text {upper }}$ (" $\mathrm{Q}_{\mathrm{s}}$ ") and $\mathrm{O}$

(" $\mathrm{O}_{\mathrm{s}}$ "), respectively (Grahn et al., 2001). Equivalent attributions in terms of Daemon \& Contreiras' (1971) zonal scheme vary locally from intervals VII to most often VIII in the Parnaíba Basin (Andrade \& Daemon, 1974; Daemon, 1974, 1976; Figure 5), as also verified in the Amazonas Basin (Melo \& Loboziak, 2003).

\section{CONCLUDING REMARKS}

The data presented herein substantially confirm and improve the tentative correlation (proposed by Grahn et al., 2001 and Melo \& Loboziak, 2003) of current Devonian miospore and chitinozoan biozones with Petrobras' original regional palynozonations of the Parnaíba Basin.

Unless a consequence of sampling artifacts, the apparent absence of late Famennian miospore and chitinozoan zones in much of the Parnaíba Basin suggests that the minimum pre-"Strunian" stratigraphic gap is possibly greater there than in the adjacent Amazonas Basin, where only the basal "Strunian" is missing locally. Such regional hiatuses probably resulted from a marked fall of relative sea-level in the late Famennian and the onset of the end-Devonian glaciation, since the sedimentary manifestations of these are more evident in the Parnaíba Basin than in the Amazonas Basin (Caputo, 1984; Loboziak et al., 2000; Streel et al., 2000a, 2001).

Devonian chitinozoan assemblages of the Parnaíba Basin seemingly evince a high degree of endemism ( $48 \%$ of the chitinozoan species are endemic, see Figure 4 and Grahn \& Melo, 2005). Hence, they exhibit only slight similarity to coeval chitinozoan faunas of Brazil and other Western Gondwanan areas, and even less similarity to those from Middle and Late Devonian strata of Laurentia. The Devonian physiogeography of the Parnaíba Basin differs remarkably from that of adjacent intracratonic basins in its shallower marine settings and more 
restricted connection to the Iapetus Ocean, which could explain the higher degree of chitinozoan endemism. Except for the early Givetian interval, the Devonian chitinozoan abundance in the Parnaíba Basin is relatively low. The comparison with well-established Devonian miospore zones of Western Gondwanan, Ardenne-Rhenish and Old Red Sandstone Continent realms facilitates reliable correlations with Western Gondwanan and global chitinozoan zones and, less directly, with the standard North Atlantic and Midcontinent U.S.A. marine faunal zonations.

\section{ACKNOWLEDGMENTS}

YG is indebted to the Faculty of Geology at Universidade do Estado do Rio de Janeiro (UERJ), and to Egberto Pereira (UERJ) for access to the facilities. JHGM thanks PetrobrasPetróleo Brasileiro S.A. for the permission to publish this paper. Edison J. Milani and Andréa W. Souto Ribeiro (both from Petrobras/Cenpes), and two anonymous peer reviewers are kindly acknowledged for the revision and improvement of the manuscript. The authors are very grateful to Geoffrey Playford (The University of Queensland) for his careful English revision of the manuscript, which led to a much improved work. YG thanks the Conselho Nacional de Desenvolvimento Científico e Tecnológico (CNPq), which made his work possible through a grant (PQ 303777/02-8).

\section{REFERENCES}

Andrade, S.M. \& Daemon, R.F. 1974. Litoestratigrafia e bioestratigrafia do flanco sudoeste da bacia do Parnaíba (Devoniano e Carbonífero). In: CONGRESSO BRASILEIRO DE GEOLOGIA, 28, 1974. Anais, São Paulo, 2:129-137.

Brito, I.M. 1967. Silurian and Devonian Acritarcha from Maranhão Basin, Brazil. Micropaleontology, 13:473-482.

Brito, I.M. 1971. Contribuição ao conhecimento dos microfósseis silurianos e devonianos da Bacia do Maranhão. V-Acritarcha Herkomorphitae e Prismatomorphitae. Anais da Academia Brasileira de Ciências, 43 (Supl.):201-208.

Brito, I.M. \& Santos, A.S. 1965. Contribuição ao conhecimento dos microfósseis silurianos e devonianos da bacia do Maranhão. I-Os Netromorphitae (Leiofusidae). Notas Preliminares e Estudos, Divisão de Geologia e Mineralogia, 129:1-23.

Caputo, M.V. 1984. Stratigraphy, tectonics, paleoclimatology and paleogeography of northern basins of Brazil. University of California, Ph.D. Dissertation, 586 p.

Cardoso, T.R.M. 1985. As coberturas do nordeste do Escudo Atlântico durante sua fase de estabilização. Universidade Federal do Rio de Janeiro, Master Thesis, 147 p.

Carozzi, A.V.; Falkenhein, F.U.H.; Carneiro, R.G.; Esteves, F.R. \& Contreiras, C.J.A. 1975. Análise ambiental e evolução tectônica sinsedimentar da seção siluro-eocarbonífera da bacia do Maranhão. Ciência - Técnica - Petróleo. Seção: Exploração de Petróleo, 7:1-48.

Collinson, C. \& Scott, A.J. 1958. Chitinozoan faunule of the Devonian Cedar Valley Formation. Illinois State Geological Survey, 247:1-34.

Cruz, N.M.C. \& Quadros, L.P. 1985. Sommerochitina langei, um novo fóssil-guia do Devoniano Superior da bacia do Parnaíba. Coletânea de Trabalhos Paleontológicos, Ser. Geologia, 27:289-293.
Daemon, R.F. 1974. Palinomorfos-guias do Devoniano Superior e Carbonífero Inferior das bacias do Amazonas e Parnaíba. Anais da Academia Brasileira de Ciências, 46:549-587.

Daemon, R.F. 1976. Correlação bioestratigráfica entre os sedimentos do Siluriano, Devoniano e Carbonífero Inferior das bacias do Amazonas, Parnaíba e Paraná. In: CONGRESSO BRASILEIRO DE GEOLOGIA, 29, 1976. Anais, Ouro Preto, 2:189-194.

Daemon, R.F. \& Contreiras, C.J.A. 1971. Zoneamento palinológico da bacia do Amazonas. In: CONGRESSO BRASILEIRO DE GEOLOGIA, 25, 1972. Anais, São Paulo, 3:79-88.

Dino, R.; Melo, J.H.G. \& Grahn, Y. 1996. Devonian palynomorphs from the western border of the Parnaíba Basin, Tocantins valley region, northern Brazil. In: INTERNATIONAL PALYNOLOGICAL CONGRESS, 9, 1996. Program and Abstracts, Houston, p. 34.

Gaugris, K.A. \& Grahn, Y. 2006. New chitinozoan species from the Devonian of the Paraná Basin, south Brazil, and their biostratigraphic significance. Ameghiniana, 43:293-310.

Grahn, Y. 1992. Revision of Silurian and Devonian strata of Brazil. Palynology, 16:35-61.

Grahn, Y. 2002. Upper Silurian and Devonian Chitinozoa from central and southern Bolivia, central Andes. Journal of South American Earth Sciences, 15:315-326.

Grahn, Y. 2005. Devonian chitinozoan biozones of Western Gondwana. Acta Geologica Polonica, 55:211-227.

Grahn, Y.; Bergamaschi, S. \& Pereira, E. 2002. Middle and Upper Devonian chitinozoan biostratigraphy of the Paraná Basin in Brazil and Paraguay. Palynology, 26:135-165.

Grahn, Y.; Loboziak, S. \& Melo, J.H.G. 2001. Integrated miosporechitinozoan biozonation of the Parnaíba Basin and its correlation with Petrobras (Müller 1962) Silurian-Lower Carboniferous palynozones. Ciência-Técnica-Petróleo. Seção: Exploração de Petróleo, 20:81-89.

Grahn, Y. \& Melo, J.H.G. 2004. Integrated Middle Devonian chitinozoan and miospore zonation of the Amazonas Basin, northern Brazil. Revue de Micropaléontologie, 47:71-85.

Grahn, Y. \& Melo, J.H.G. 2005. Middle and Late Devonian Chitinozoa and biostratigraphy of the Parnaíba and Jatobá basins, northeastern Brazil. Palaeontographica B, 272:1-50.

Grahn, Y.; Melo, J.H.G. \& Steemans, P. 2005. Integrated chitinozoan and miospore zonation of the Serra Grande Group (SilurianLower Devonian), Parnaíba Basin, northeast Brazil. Revista Española de Micropaleontología, 37:183-204.

Lange, F.W. 1952. Quitinozoários do Folhelho Barreirinha, Devoniano do Pará. Dusenia, 3:373-386.

Lange, F.W. 1967. Biostratigraphic subdivision and correlation of the Devonian in the Paraná Basin. Boletim Paranaense de Geociências, 21/22:63-98.

Loboziak, S.; Caputo, M.V. \& Melo, J.H.G. 2000. Middle DevonianTournaisian miospore biostratigraphy in the southwestern outcrop belt of the Parnaíba Basin, north-central Brazil. Revue de Micropaléontologie, 43:301-318.

Loboziak, S. \& Melo, J.H.G. 2000. Miospore events from late Early to Late Devonian strata of Western Gondwana. Géobios, 33:399-407.

Loboziak, S. \& Melo, J.H.G. 2002. Devonian miospore successions of Western Gondwana: update and correlation with Southern Euramerican miospore zones. Review of Palaeobotany and Palynology, 121:133-148.

Loboziak, S.; Melo, J.H.G.; Matsuda, N.S. \& Quadros, L.P. 1997a. Miospore biostratigraphy of the type Barreirinha Formation (Curuá Group, Upper Devonian) in the Tapajós River area, Amazon Basin, north Brazil. Bulletin des Centres de Recherches 
Exploration-Production Elf Aquitaine, 21:187-205.

Loboziak, S.; Melo, J.H.G.; Quadros, L.P. \& Streel, M. 1997b. Palynological evaluation of the Famennian Protosalvinia (Foerstia) Zone in the Amazon Basin, northern Brazil. Review of Palaeobotany and Palynology, 96:31-45

Loboziak, S.; Streel, M. \& Burjack, M.I. 1988. Miospores du Dévonien moyen et supérieur du Bassin du Paraná, Brésil: systématique et stratigraphie. Sciences Géologiques, Bulletin, 41:351-377.

Loboziak, S.; Streel, M.; Caputo, M.V. \& Melo, J.H.G. 1992. Middle Devonian to Lower Carboniferous miospore stratigraphy in the central Parnaíba Basin (Brazil). Annales de la Societé Géologique de Belgique, 115:215-226.

Loboziak, S.; Streel, M.; Caputo, M.V. \& Melo, J.H.G. 1993. Middle Devonian to Lower Carboniferous miospores from selected boreholes in Amazonas and Parnaíba basins (Brazil): additional data, synthesis, and correlation. Documents des Laboratoires de Géologie de Lyon, 125:277-289.

Maziane, N.; Higgs, K. \& Streel, M. 1999. Revision of the late Famennian miospore zonation scheme in eastern Belgium. Journal of Micropalaeontology, 18:17-25.

Melo, J.H.G. 1988. The Malvinokaffric Realm in the Devonian of Brazil. In: N.J. McMillan; A.F. Embry \& D.J. Glass (eds.) Devonian of the World. Canadian Society of Petroleum Geologists Memoir, 14(1):669-703.

Melo, J.H.G. 2000. Palynological evaluation and correlation of some Silurian-Devonian sections of southern Bolivia. In: CONGRESO GEOLÓGICO BOLIVIANO, 14, 2000, Memorias, La Paz, p. 136-141.

Melo, J.H.G. \& Loboziak, S. 2000. Viséan miospore biostratigraphy and correlation of the Poti Formation (Parnaíba Basin, northern Brazil). Review of Palaeobotany and Palynology, 112:147-165.

Melo, J.H.G. \& Loboziak, S. 2001. New miospore zonation of Devonian-Early Carboniferous strata in the Amazon Basin: a preliminary account. Ciência-Técnica-Petróleo. Seção: Exploração de Petróleo, 20:99-107.

Melo, J.H.G. \& Loboziak, S. 2003. Devonian-Early Carboniferous miospore biostratigraphy of the Amazon Basin, northern Brazil. Review of Palaeobotany and Palynology, 124:131-202.

Melo, J.H.G.; Loboziak, S. \& Streel, M. 1999. Latest Devonian to early Late Carboniferous biostratigraphy of northern Brazil: an update. Bulletin du Centre de Recherches Elf Exploration Production, 22:13-33.

Molyneux, S.G.; Le Hérissé, A. \& Wicander, R. 1996. Paleozoic phytoplankton. In: J. Jansonius \& D.C. McGregor (eds.) Palynology: principles and applications, American Association of Stratigraphic Palynologists Foundation, 2:493-529.

Müller, H. 1962. Report on palynological results of samples examined from wells in Maranhão. Petrobras/Rpba Internal Report, 44 p.

Niklas, K.J.; Phillips, T.L. \& Carozzi, A.V. 1976. Morphology and paleoecology of Protosalvinia from the Upper Devonian (Famennian) of the Middle Amazon Basin of Brazil. Palaeontographica B, 155:1-30.

Ottone, E.G. 1996. Devonian palynomorphs from the Los Monos Formation, Tarija Basin, Argentina. Palynology, 20:105-155.

Paris, F.; Winchester-Seeto, T.; Boumendjel, K. \& Grahn, Y. 2000. Toward a global biozonation of Devonian chitinozoans. Courier Forschungsinstitut Senckenberg, 220:39-55.

Quadros, L.P. 1982. Distribuição bioestratigráfica dos Chitinozoa e Acritarchae na bacia do Parnaíba. Ciência-Técnica-Petróleo, Seção: Exploração de Petróleo, 12:1-76.

Racheboeuf, P.R.; Le Hérissé, A.; Paris, F.; Babin, C.; Guillocheau, F.; Truyols-Massoni, M. \& Suárez-Suroco, R. 1993. Le Dévonien de Bolivie; biostratigraphie et chronostratigraphie. Comptes Rendus d'Academie des Sciences de Paris (Ser. II), 317:795-802.

Regali, M.S.P. 1964. Resultados palinológicos de amostras paleozóicas da bacia de Tucano-Jatobá (seção paleozóica do poço Imst-1-Pe na Bacia de Jatobá). Boletim Técnico da Petrobras, 7:165-180.

Richardson, J.B. \& Ahmed, S. 1988. Miospore zonation and correlation of Upper Devonian sequences from western New York State and Pennsylvania. Canadian Society of Petroleum Geologists Memoir, 14(3):541-558.

Richardson, J.B. \& McGregor, D.C. 1986. Silurian and Devonian spore zones of the Old Red Sandstone Continent and adjacent regions. Geological Survey of Canada Bulletin, 364:1-79, appendices.

Rodrigues, R.; Loboziak, S.; Melo, J.H.G. \& Alves, D.B. 1995. Geochemical characterization and miospore biochronostratigraphy of the Frasnian anoxic event in the Parnaíba Basin, northeast Brazil. Bulletin des Centres de Recherches Exploration-Production Elf Aquitaine, 19:319-327.

Sommer, F.W, \& Boekel, N.M. van. 1964. Quitinozoários do Devoniano de Goiás. Anais da Academia Brasileira de Ciências, 36:423-431.

Streel, M. 1986. Miospore contribution to the upper FamennianStrunian event stratigraphy. Annales de la Société Géologique de Belgique, 109 (special volume):75-92.

Streel, M.; Caputo, M.V.; Loboziak, S. \& Melo, J.H.G. 2000a. Late Frasnian-Famennian climates based on palynomorph quantitative analyses and the question of the Late Devonian glaciations. Earth Science Reviews, 52:121-173.

Streel, M.; Caputo, M.V.; Loboziak, S.; Melo, J.H.G. \& Thorez, J. 2001. Palynology and sedimentology of laminites and tillites from the latest Famennian of the Parnaíba Basin, Brazil. Geologica Belgica, 3:87-96.

Streel, M.; Higgs, K.; Loboziak, S.; Riegel, W. \& Steemans, P. 1987. Spore stratigraphy and correlation with faunas and floras in the type marine Devonian of the Ardenne-Rhenish regions. Review of Palaeobotany and Palynology, 50:211-229.

Streel, M. \& Loboziak, S. 1987. Nouvelle datation par miospores du Givétien-Frasnien des sediments non marins du sondage de Booischot (Bassin de Campine, Belgique). Bulletin de la Société Belge de Géologie, 96:99-106.

Streel, M.; Loboziak, S.; Steemans, P. \& Bultynck, P. 2000 b. Devonian miospore stratigraphy and correlation with the global stratotype sections and points. Courier Forschungsinstitut Senckenberg, 220:9-23.

Urban, J.B. \& Newport, R.L. 1973. Chitinozoa of the Wapsipinicon Formation (Middle Devonian) of Iowa. Micropaleontology, 19:239-246.

Witzke, J.B.; Bunker, B.J. \& Rogers, F.S. 1988. Eifelian through lower Frasnian stratigraphy and deposition in the Iowa area, Central Midcontinent, U.S.A. Canadian Society of Petroleum Geologists Memoir, 14(1):221-250.

Wright, R.P. 1980. Middle Devonian Chitinozoa of Indiana. Indiana Geological Survey Special Report, 18:1-34.

Received in May, 2006; accepted in October 2006 
Appendix 1. List of miospore species cited in text and figures. Acinosporites acanthomammillatus Richardson 1965

Acinosporites lindlarensis Riegel 1968

Acinosporites macrospinosus Richardson 1965

Aratrisporites saharaensis Loboziak, Clayton \& Owens 1986

Archaeozonotriletes chulus (Cramer) Richardson \& Lister 1969 Archaeozonotriletes variabilis Naumova emend. Allen 1965

Aurospora macra Sullivan 1968

Aurospora pseudocrista Ahmed 1980

Camarozonotriletes? concavus Loboziak \& Streel 1989

Chelinospora ligurata Allen 1965

Chelinospora paravermiculata Loboziak, Streel \& Burjack 1988

Chelinospora timanica (Naumova) Loboziak \& Streel 1989

Cordylosporites marciae Playford \& Satterthwait 1985

Cordylosporites spathulatus (Winslow) Playford \& Satterthwait 1985

Craspedispora ghadamisensis Loboziak \& Streel 1989

Craspedispora paranaensis Loboziak, Streel \& Burjack 1988

Cymbosporites catillus Allen 1965

Cymbosporites cyathus Allen 1965

Diatomozonotriletes franklinii McGregor \& Camfield 1982

Dictyotriletes emsiensis (Allen) McGregor 1973

Diducites mucronatus (Kedo) van Veen 1981

Emphanisporites annulatus McGregor 1961

Geminospora lemurata Balme emend. Playford 1983

Geminospora piliformis Loboziak, Streel \& Burjack 1988

Geminospora punctata Owens 1971

Grandispora douglastownense McGregor 1973

Grandispora incognita (Kedo) McGregor \& Camfield 1976

Grandispora libyensis Moreau-Benoit 1980

Grandispora macrotuberculata (Arkhangelskaya) McGregor 1973

Grandispora maculosa Playford \& Helby 1968

Grandispora mammillata Owens 1971

Grandispora megaformis (Richardson) McGregor 1973

Grandispora microseta (Kedo) Becker, Bless, Streel \& Thorez 1974

Grandispora permulta (Daemon) Loboziak, Streel \& Melo 1999

Grandispora spiculifera Playford 1976

Indotriradites explanatus (Luber) Playford 1991

Knoxisporites dedaleus (Naumova) Streel 1977

Knoxisporites hederatus (Ishchenko) Playford 1963

Knoxisporites literatus (Waltz) Playford 1963

Lophozonotriletes media Taugourdeau-Lantz 1987

Radiizonates arcuatus Loboziak, Playford \& Melo 2000

Retispora lepidophyta (Kedo) Playford 1976

Rugospora bricei Loboziak \& Streel 1989

Rugospora radiata (Jushko) Byvsheva 1985

Samarisporites triangulatus Allen 1965

Samarisporites sp. E sensu Streel \& Loboziak 1987

Spelaeotriletes granulatus (Kedo) Moreau-Benoit 1980

Teichertospora torquata (Higgs) McGregor \& Playford 1990

Tumulispora rarituberculata (Luber) Potonié 1966

Vallatisporites hystricosus (Winslow) Byvsheva 1985

Vallatisporites vallatus Hacquebard 1957

Vallatisporites verrucosus Hacquebard 1957

Verrucosisporites bulliferus Richardson \& McGregor 1986

Verrucosisporites nitidus Playford 1964

Verrucosisporites premnus Richardson 1965

Verrucosisporites scurrus (Naumova) McGregor \& Camfield 1982
Appendix 2. List of chitinozoan species cited in text and figure 4. Alpenachitina eisenacki Dunn \& Miller 1964

Ancyrochitina cf. A. ancyrea (Eisenack 1931)

Ancyrochitina arirambaense Grahn \& Melo 2005

Ancyrochitina cornigera Collinson \& Scott 1958

Ancyrochitina langei Sommer \& Boekel 1964

Ancyrochitina aff. A. langei Sommer \& Boekel 1964

Ancyrochitina latipes Collinson \& Scott 1958

Ancyrochitina morzadeci Paris 1981

Ancyrochitina cf. A. morzadeci Paris 1981

Ancyrochitina postdesmea Grahn 2002

Ancyrochitina simplex Grahn 2002

Ancyrochitina taouratinensis Boumendjel 1985

Ancyrochitina sp. A sensu Grahn \& Melo 2005

Ancyrochitina sp. B sensu Grahn \& Melo 2005

Ancyrochitina sp. C sensu Grahn \& Melo 2005

Ancyrochitina sp. D sensu Grahn \& Melo 2005

Ancyrochitina sp. E sensu Grahn \& Melo 2005

Ancyrochitina sp. F sensu Grahn \& Melo 2005

Angochitina cf. A. cyrenaicensis Paris 1988

Angochitina daemoni Grahn 2000

Angochitina aff. A. daemoni Grahn 2000

Angochitina katzeri Grahn \& Melo 2002

Angochitina mourai Lange 1952

Angochitina parnaibaense Grahn \& Melo 2005

Angochitina rathbuni Grahn \& Melo 2002

Angochitina smalli Grahn \& Melo 2005

Angochitina sp. A sensu Grahn \& Melo 2005

Angochitina sp. B sensu Grahn \& Melo 2005

Angochitina sp. C sensu Grahn \& Melo 2005

Angochitina sp. D sensu Grahn \& Melo 2005

Angochitina sp. E sensu Grahn \& Melo 2005

Angochitina sp. F sensu Grahn \& Melo 2005

Angochitina sp. G sensu Grahn \& Melo 2005

Angochitina sp. H sensu Grahn \& Melo 2005

Eisenackitina aranea (Urban 1972)

Fungochitina microspinosa Grahn \& Melo 2005

Fungochitina pilosa Collinson \& Scott 1958

Hoegisphaera glabra Staplin 1961

Hoegisphaera cf. H. glabra Staplin 1961

Lagenochitina avelinoi Lange 1952

Lagenochitina sommeri (Lange 1952)

Lagenochitina sp. A sensu Grahn \& Melo 2005

Lagenochitina sp. B sensu Grahn \& Melo 2005

Linochitina jardinei Boumendjel 1985

Plectochitina n. sp. A sensu Grahn \& Melo 2005

Ramochitina cf. R. aurita (Wrona 1980)

Ramochitina cf. R. boliviensis Grahn 2002

Ramochitina kegeli Grahn \& Melo 2005

Ramochitina cf. R. oliverai Grahn \& Melo 2002

Ramochitina pimenteiraense Grahn \& Melo 2005

Ramochitina ramosi Sommer \& Boekel 1964

Ramochitina stiphrospinata Grahn \& Melo 2005

Ramochitina sp. A sensu Grahn \& Melo 2005

Ramochitina sp. B sensu Grahn \& Melo 2005

Ramochitina sp. C sensu Grahn \& Melo 2005

Sommerochitina langei Cruz \& Quadros 1985

Sommerochitina cf. S. langei Cruz \& Quadros 1985

Spinachitina aff. S. biconstricta sensu Quadros 1982 (non Lange 1949)

Urochitina bastosi Boekel 1967 